\title{
Quality Characteristics of Crackers Made From Kasuri Methi and Different Flours
}

\author{
Karad V. A. ${ }^{1}$, Jangale R. S. ${ }^{2}$, Karad K. A. ${ }^{3}$ \\ ${ }^{1}$ Research Scholar, K. K. Wagh College of Food Technology, Nashik Maharashtra, India
}

${ }^{2}$ Assistant Professor, Department of Food Chemistry and Nutrition, K. K. Wagh College of Food Technology, Nashik, Maharashtra, India

${ }^{3}$ Research Scholar, K. K. Wagh College of Food Technology, Nashik, Maharashtra, India

\begin{abstract}
The methi crackers were prepared as ready to eat enriched with Fenugreek which is one of the well-known spices in human food. Kasuri Methi (Trigonella foenum-gracum) is very famous for its appetizing fragrance and it is used for culinary preparation. It provides more dietary fibre due to its high fibre content and it has an ability to change food texture. Crackers was produced from the mixture of various flours (refined wheat flour, wheat flour, bengal gram flour and soya flour) and spices (Kasuri methi, red chili power, black pepper, cumin seed and Carom seeds) at different combination. Proximate analysis and sensory analysis were carried out on the crackers for their quality evaluation. The proximate analysis were determined using standard methods.From the result of proximate analysis, the moisture content ranged in values from 3.7-4\%. Also the other components of ash, fat, protein and carbohydrate were in the ranges of 0.35-0.45\%, 29.2-32.5\%, 6.1-9.81\% and 50.4-55.2\% respectively. Sensory evaluation was done to know the acceptability of methi crackers. It include colour, taste, flavour, texture, appearance and overall acceptability. The sample C scored high score for overall acceptability i.e.8.2. The colour ranged in values from 7.5-8.1. Also the other components of taste, flavour, texture, appearance and overall acceptability were in the ranges of 7.2-7.8, 7.3-7.6, 7.5-7.8, 7.4-7.6 and 7.9-8.2 respectivily. On the basis of proximate analysis and sensory evaluation the sample $C$ was selected.
\end{abstract}

Keywords: Kasuri Methi, Crackers, proximate analysis, Sensory evaluation

\section{Introduction}

Bakery industry in India is considered as one of the major food processing industry with an annual demand of over 2758 MT [1]. India is known to be the second largest manufacturer of biscuits, first being USA. Bakery products are the most popular food consumed by all age groups and are gaining popularity as processed foods because of their availability, ready to eat convenience, and comparatively good shelf life [2].

Generally the term crackers covers wide range of products similar to semi sweet machine cut cookies to fermented, crisp, non-sweet, laminated items. The crackers are similar to the chemically leavened products; include the categories of the semi-sweet gram crackers and the highly flavoured snack crackers with pre dominant onion, garlic, caraway, smoked yeast, cheese etc. flavours. Among the fermented types of crackers, the soda or salty crackers are the most common [3].

Fenugreek is cultivated all over the world as a semi-arid crop. It has got different names as per the locality. Fenugreek is one of the well known spices in human food. Its seeds and green leaves are used in food as well as in medicinal application which is an old practice of human history. It provides natural food fibre and other nutrients required in human body [4]. Fenugreek has strong spicy and seasoning type sweet flavour [5]. Aromatic and flavourful fenugreek is a popular spice and is widely used for well recognized culinary and medicinal properties [6]. "Kasuri Methi" is very famous for its appetizing fragrance and it is used for culinary preparations [7]. In recent trend, fenugreek is also used as spice adjunct [8]. India is a major producer of fenugreek and also a major consumer of it for its culinary uses and medicinal application. It is used in functional food, traditional food, and nutraceuticals as well as in physiological utilization such as antibacterial, anticancer, antiulcer, anthelmintic, hypocholesterolemic, hypoglycaemic, antioxidant, and antidiabetic agent. It has beneficial influence on digestion and also has the ability to modify food texture.

\section{Materials and Methods}

\subsection{Material Procurement}

The refined wheat flour, wheat flour, bengal gram flour, soya flour, kasuri methi is a basic material used for the preparation of methi crackers. And other ingredients used in the preparation of crackers included Sugar, salt, Red chilli powder, black pepper, cumin seed, Carom seeds, butter and baking powder were obtained from local market of Nashik. The equipments and chemicals were obtained from the Department of Food Science and Technology.

Table 1: Standardized procedure for Methi Crackers (per $100 \mathrm{gm}$.)

\begin{tabular}{|c|l|l|}
\hline Sr. No. & \multicolumn{1}{|c|}{ Ingredient } & Amount $(\mathrm{gm})$ \\
\hline 1 & Refined Wheat flour (Maida) & \multicolumn{1}{|c|}{60} \\
\hline 2 & Wheat flour & 20 \\
\hline 3 & Bengal gram flour & 14 \\
\hline 4 & Soya flour & 6 \\
\hline 5 & Kasuri methi & 0.5 \\
\hline 6 & Red chilli powder & 1 \\
\hline 7 & Sugar & 3 \\
\hline 8 & Salt & 3 \\
\hline 9 & Black pepper & 0.5 \\
\hline 10 & Cumin seed & 0.5 \\
\hline 11 & Carom seeds & 0.5 \\
\hline 12 & Baking powder & 3 \\
\hline 13 & Butter & 40 \\
\hline
\end{tabular}




\section{International Journal of Science and Research (IJSR) \\ ISSN (Online): 2319-7064}

Index Copernicus Value (2013): 6.14 | Impact Factor (2014): 5.611

Table 2: Formulation of raw material per $100 \mathrm{gm}$.

\begin{tabular}{|c|c|c|c|c|}
\hline Sr. No. & Material & Sample A & Sample B & Sample C \\
\hline 1 & Refined Wheat flour (Maida) & 40 & 50 & 60 \\
\hline 2 & Wheat flour & 40 & 30 & 20 \\
\hline 3 & Bengal gram flour & 14 & 14 & 14 \\
\hline 4 & Soya flour & 6 & 6 & 6 \\
\hline 5 & Kasuri methi & 0.5 & 0.5 & 0.5 \\
\hline 6 & Red chilli powder & 2 & 2 & 1 \\
\hline 7 & Sugar & 3 & 3 & 3 \\
\hline 8 & Salt & 3 & 3 & 3 \\
\hline 9 & Black pepper & 1 & 1 & 0.5 \\
\hline 10 & Cumin seed & 1 & 1 & 0.5 \\
\hline 11 & Carom seeds & 1 & 1 & 0.5 \\
\hline 12 & Baking powder & 3 & 3 & 3 \\
\hline 13 & Butter & 40 & 40 & 40 \\
\hline
\end{tabular}

\subsection{Procedure for Preparation of Methi Crackers}

The refined wheat flour, wheat flour, bengal gram flour, soya flour and other ingredients were weighed accurately. The weighed ingredients were mixed. Fat was added into the dry ingredients. Water was added accurately to form dough. The dough was then kneaded and rolled to a uniform thickness. The crackers were cut out with round cutter. Then the crackers were baked at $140-180^{\circ} \mathrm{C}$ for $15-20$ minutes, cooled to ambient temperature and packed in high density polyethylene bags.

\subsection{Experimental Plan}

Take good quality of refined wheat flour, wheat flour, bengal gram flour, soya flour and Sugar

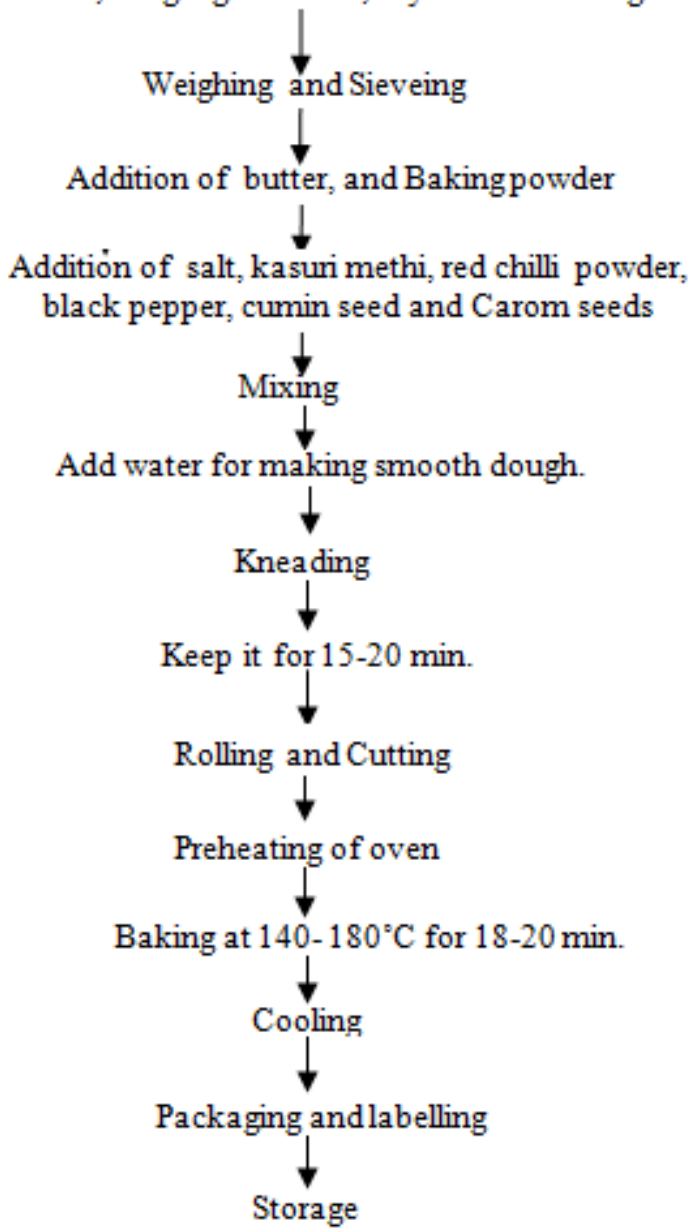

Figure 1: Process Flow Chart of Methi Crackers Preparation

\subsection{Proximate Analysis}

The moisture, ash and fat contents were determined using [9] while protein content was determined by Micro Kjeldahl method [10]. The carbohydrate Content was estimated by subtracting the sum of percentage of moisture, crude fat, crude protein and ash contents from $100 \%$.

\subsection{Sensory Evaluation}

A sensory evaluation of crackers containing various levels was evaluated initially for color, taste, flavor, texture, appearance and overall acceptability In this case; 9-point hedonic rating test was performed to assess the degree of acceptability of these crackers. Three pieces from each crackers lot was presented to panelists. The test panelists were asked to rate the sample on a 9-point hedonic scale. Water was provided for rinsing between the samples. Panelists were required to evaluate the color, taste, flavor, texture, appearance and overall acceptance of the crackers using the 9-point hedonic scale with $1=$ dislike extremely, $2=$ dislike very much, $3=$ dislike moderately, 4=dislike slightly, 5=neither like nor dislike, $6=$ like slightly, 7=like moderately, $8=$ like very much, and $9=$ like extremely.

\section{Results and Discussion}

\subsection{Proximate Analysis}

The proximate analysis of methi crackers are listed in table 3. Crackers are dried product, it expected to low moisture content the sample $\mathrm{C}$ content $3.7 \%$ moisture and it is low as compared to other sample i.e. $3.9 \%$ and $4 \%$. From the result, ash content ranged between $0.35-0.45 \%$. From the result sample $\mathrm{C}$ content higher protein than the other sample i.e. $9.81 \%$. The fat content in methi crackers ranged between 29.2-32.5\%. Sample C content low fat so it is desirable (Fig.2). High fat cause rancidity in food leading to development of unpleasant and odorous compound. Carbohydrate content ranged between 50.4-55.2\%. The sugar content of sample $\mathrm{C}$ is $3.06 \%$ and the other sample content sugar $4.9-5.10 \%$ respectively.

Table 3: Proximate analysis of methi crackers

\begin{tabular}{|c|c|c|c|}
\hline Particulars & $\begin{array}{c}\text { Sample A } \\
\text { Result (\%) }\end{array}$ & $\begin{array}{c}\text { Sample B } \\
\text { Result (\%) }\end{array}$ & $\begin{array}{c}\text { Sample C } \\
\text { Result (\%) }\end{array}$ \\
\hline Crude Protein & $6.1 \pm 0.45$ & $8.91 \pm 0.50$ & $9.81 \pm 0.56$ \\
\hline Crude Fat & $32.5 \pm 0.67$ & $30.7 \pm 0.60$ & $29.2 \pm 0.58$ \\
\hline Carbohydrate & $50.4 \pm 0.5$ & $54.4 \pm 0.7$ & $55.2 \pm 0.9$ \\
\hline Sugar & $4.9 \pm 0.09$ & $5.10 \pm 0.17$ & $3.06 \pm 0.07$ \\
\hline Moisture content & $4 \pm 0.40$ & $3.9 \pm 0.35$ & $3.7 \pm 0.31$ \\
\hline Ash & $0.45 \pm 0.11$ & $0.40 \pm 0.09$ & $0.35 \pm 0.07$ \\
\hline
\end{tabular}




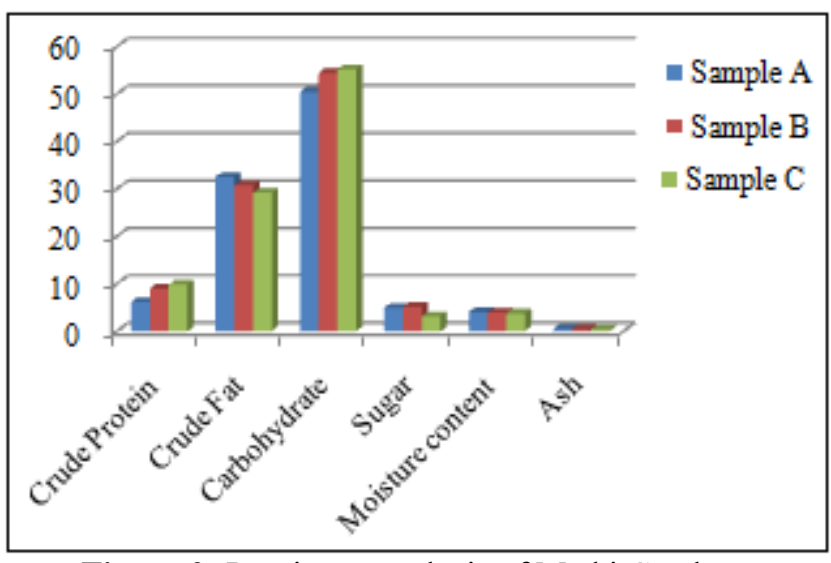

Figure 2: Proximate analysis of Methi Crackers

\subsection{Sensory Evaluation}

Sensory evaluation consists of different attribute considered were appearance, color, flavor, texture, taste and overall acceptability (Fig.3). Average values of each attribute for respective sample is given in Table 4. From the result sample $\mathrm{C}$ was selected which contains refined wheat flour, wheat flour, Bengal gram flour, soya flour, Kasuri methi, red chilli powder, sugar, salt, black pepper, cumin seed, Carom seeds, baking powder and butter in the proportion of $(60,20,14,6$, $0.5,1,3,3,0.5,0.5,0.5,3,40)$ respectively it ranked highest with a mean value of 8.2. This was very close to the sample $\mathrm{B}$ and $\mathrm{A}$. Based on colour sample $\mathrm{C}$ ranked highest with a mean value of 8.1 . This was very close to the sample $B$ and A. Flavour is determining factor in consumer acceptance of crackers it can deduct that the crackers is accepted by the sample $\mathrm{C}$ the mean value was 7.6. The taste result shows that the sample $\mathrm{C}$ had the highest mean score of 7.8 and this was closely to the sample B and A. with mean score of 7.7 and 7.2 respectively and there was no significant difference between them. On the basis of texture sample $\mathrm{C}$ was accepted the mean score of 7.8. For the appearance the highest mean score is for sample C i.e. 7.6.

Table 4: Average score of sensory evaluation of methi crackers

\begin{tabular}{|c|c|c|c|}
\hline \multicolumn{5}{|c|}{ crackers } \\
\hline Parameters & Sample A & Sample B & Sample C \\
\hline Colour & 7.5 & 7.7 & 8.1 \\
\hline Taste & 7.2 & 7.7 & 7.8 \\
\hline Flavour & 7.3 & 7.4 & 7.6 \\
\hline Texture & 7.5 & 7.7 & 7.8 \\
\hline Appearance & 7.4 & 7.7 & 7.7 \\
\hline Overall Acceptability & 7.9 & 8 & 8.2 \\
\hline
\end{tabular}

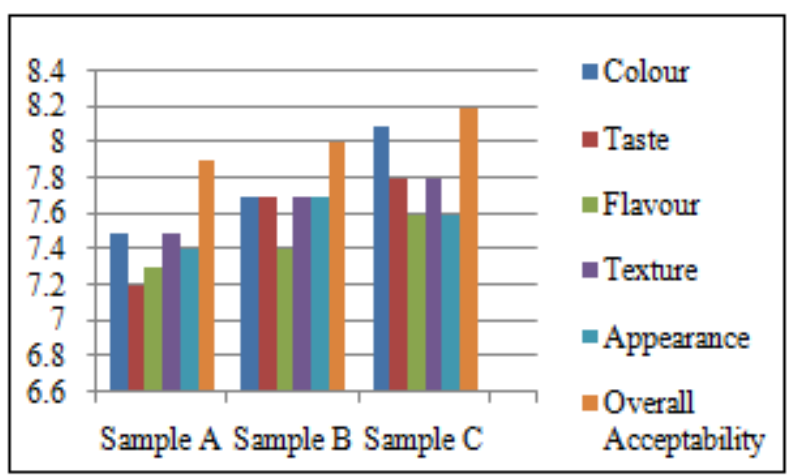

Figure 3: Sensory analysis Chart of Methi Crackers

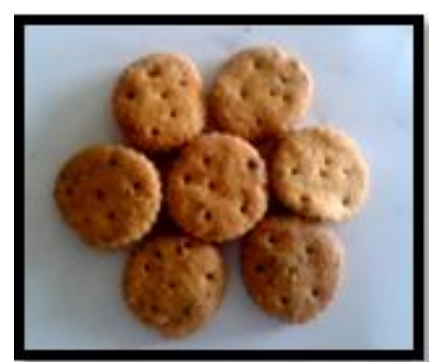

Figure 4: Methi Crackers

\section{Conclusion}

It was found that methi contain high fibre content and it has an ability to change food texture. Incorporation of Wheat flour (20), Bengal gram flour (14), Soya flour (6), Kasuri Methi (0.5), Red chilli powder (1), Sugar (3), Salt (3), Black pepper (0.5), Cumin seed (0.5), Carom seeds (0.5), Baking powder (3), Butter (40) was found to be the most acceptable combination in crackers making with respect to nutritional, textural and organoleptic qualities of crackers (Fig.4). The protein content in sample $\mathrm{C}$ is higher than other sample i.e. $9.81 \%$ and fat content is lower than other sample i.e. $29.2 \%$. Thus it was beneficial for health.

\section{References}

[1] Ministry of Food Processing Industries, Govt. of India, New Delhi. (2013). Retrieved on April 02, 2013, from www.mofpi.nic.in

[2] Bala A., Gul K. and Riar C.S. (2015). Functional and sensory properties of cookies prepared from Wheat flour supplemented with cassava and water chestnut flours. Cogent Food \& Agriculture 1(10): 1-7.

[3] EIRI Consultants and Engineers, Modern Bakery Technology and Fermented Cereal Products with Formulae, Engineers India Research institute, Delhi.

[4] Thomas J.E, Bandara M, Lee E.L, Driedger D, Acharya S (2011) Biochemical monitoring in fenugreek to develop functional food and medicinal plant variants. $\mathrm{N}$ Biotechnol 28: $110-117$.

[5] Blank I (1996) The flavor principle of fenugreek. Nestlé research center. $211^{\text {th }}$ ACS Symposium. New Orleans 2428.

[6] Sowmya P, Rajyalakshmi P (1999) Hypocholesterolemic effect of germinated fenugreek seeds in human subjects. Plant Foods Hum Nutr 53: 359-365.

[7] Brar JK, Rai DR, Singh A, Kaur N (2011) Biochemical and physiological changes in fenugreek (Trigonellafoenumgraceum L.) leaves during storage under modified atmosphere packaging. Journal food science and technology.

[8] Senthil A, Mamatha BS, Vishwanath P, Bhat KK Ravishankar GA (2010) Studies on development and storage stability of instant spice adjunct mix from seaweed. Journal of food science and technology 48: 6 .

[9] AOAC (1984). Official method of Analysis. Association of Official analytical Chemist, $13^{\text {th }}$ edition. Washington D.C.278-310.

[10] Pearson, D. (1976). The chemical Analysis of Food. 7 thedition Churchill Livingstone Edinburgh, London and New York, 27-72. 